IRAKS SUNNIMUSLIMER ETTER 2003

\title{
Fra priviligert minoritet til politisk paria?
}

Iraks sunnimuslimer var minoriteten som styrte landet - hva har skjedd med dem etter fallet fra makten?

Ane Mannsåker Roald er stipendiat ved Universitetet i Oslo og redaksjonsmedlem i Babylon. 
TEKST: Ane Mannsåker Roald

SYSTEMSKIFTET I BAGDAD har gitt en ny hverdag for de arabiske sunnimuslimene i Irak. Samfunnet har gjennomgått voldsomme omveltninger, og sunniene har mistet mye av makten de en gang hadde. Hvorfor har betydningen av religiøs tilhørighet økt? Og hva har dette å si for hvordan sunnimuslimene organiserer seg politisk?

\section{Nye tider}

Iraks sunnimuslimer utgjør mellom I5 og 20 prosent av befolkningen, ${ }^{2}$ men har tradisjonelt sett dominert de mektigste samfunnsinstitusjonene i landet som regjering, hær, fagforeninger og politisk system. En viktig sunni-bastion var Ba'th-partiet, som ble styrt av Saddam Hussein og hans nære medarbeidere. Medlemskap i partiet var ofte en nødvendighet for å gjøre karriere i det irakiske embetsverket, og mange var medlemmer uten nødvendigvis å sympatisere særlig med ideologien til partiet.

Religiøst sett vil de fleste mene at forskjellene mellom sunni- og sjiamuslimer er små. De grunnleggende religiøse prinsippene er de samme, og det har også vært vanlig med giftemål på tvers av de sekteriske skillelinjene i Irak. Det er likevel ubestridelig at sunnimuslimer har vært overrepresentert i landets maktposisjoner, ikke bare under Saddam Hussein, men helt siden Bagdad falt inn under Det ottomanske riket. Med regimeskiftet i 2003 er dette endret, og situasjonen for Iraks sunnimuslimer ser ganske annerledes ut i dag.

\section{Valg og boikott}

De viktigste politiske prosessene som har ligget til grunn for disse endringene skjedde i 2005. Det året gikk irakerne til valgurnene tre ganger: i januar for å velge midlertidig nasjonalforsamling, deretter for å stemme over utkast til ny grunnlov i oktober, før de til sist valgte ordinær nasjonalforsamling i desember.

Den midlertidige nasjonalforsamlingen skulle sørge for å få laget en ny grunnlov og å arrangere nytt valg til ordinær nasjonalforsamling. Før januarvalget var det mange som mente at valget var illegitimt fordi det ble avholdt under okkupasjon. Av denne grunn valgte blant annet de to viktigste religiøst baserte sunnipartiene, Muslim Scholars Association ${ }^{3}$ og Iraqi Islamic Party, ${ }^{4}$ å boikotte valget og oppfordret sine sympatisører til å gjøre det samme. De sekulært orienterte sunnipartiene, som for eksempel Adnan Pachachis Assembly of Independent Democrats, ${ }^{5}$ var på sin side 
ivrige tilhengere av deltagelse $i$ den politiske prosessen. ${ }^{6}$ På selve valgdagen viste det seg imidlertid at sunnimuslimene i bare liten grad hadde møtt opp for å gi sin stemme, i sterk kontrast til sjiamuslimer og kurdere.

Både den politiske boikotten og sikkerhetssituasjonen spilte inn på valgdeltagelsen. I Bagdad var det 48 prosent valgdeltagelse, mens tilsvarende tall for Diyala like nordøst for Bagdad var så lavt som 34 prosent.7 I Anbar, hvor det voldelige opprøret sto sterkest, hadde bare to prosent av velgerne funnet veien til valglokalene. ${ }^{8}$ Til sammenligning hadde det kurdiskdominerte Dohuk 89 prosent oppmøte, mens sjiadominerte Karbala hadde 73 prosent. ${ }^{9}$

Resultatet ble dermed at de partiene som representerte sunnimuslimske interesser, fikk en uforholdsmessig lav representasjon i den midlertidige nasjonalforsamlingen. Daværende president Ghazi alYawers Iraqis $^{\text {Io }}$ vant fem seter, mens Pachachis Assembly of Independent Democrats ikke engang greide å vinne ett eneste, og dermed var det bare en håndfull sunnirepresentanter i parlamentet.

\section{Grunnlovsprosess og utestengelse}

Så lenge nasjonalforsamlingen, valgt $\mathrm{i}$ januar, var nettopp midlertidig, skulle man kanskje tro at det ikke var så problematisk om noen grupper fikk litt for lav representasjon. Det katastrofalt dårlige resultatet for sunniene hadde likevel store implikasjoner for den videre prosessen siden komiteen som skulle forberede utkastet til den nye grunnloven, utgikk fra dette midlertidige parlamentet. Det var viktige spørsmål som føderalstat, fordeling av oljeinntekter og shari'as status i lovverket, som sto på spill, og det var viktig at prosessen ble oppfattet som legitim i hele befolkningen.

Forventningene om at også sunnimuslimer ville få delta i grunnlovsarbeidet var da også store, men da komiteen ble utnevnt av overgangsregjeringen i mai 2005, var bare to av 56 medlemmer sunnimuslimer. ${ }^{\text {II }}$ I ukene som fulgte var synspunktene mange, men I3. juni 2005 ble sunnimuslimene tilbudt å få ytterligere I5 representanter i komiteen. Det var en uttrykt ambisjon at arbeidet skulle gjøres etter konsensusprinsippet for å unngå en avstemning der de tunge aktørene overkjørte mindretallet. ${ }^{\mathrm{I} 2}$

Nå begynte imidlertid komiteen å føle et visst tidspress, for i følge lovverket som regulerte prosessen fram mot ny grunnlov, måtte utkastet være ferdig senest I5. august 2005. Særlig i saker som føderalisme, fordeling av oljeinntekter mellom føderalstat og regioner og de-Ba'thifiseringsprogrammet, hadde sunnimuslimene problemer med å godta posisjonene til sjiaene og kurderne. Etter en ukes utsettelse ble utkastet levert på tross av at sunnirepresentantene fortsatt ikke følte at de kunne stå inne for produktet.

Forhandlingene fortsatte så på bakrommet $\mathrm{i}$ ytterligere noen dager før det ble satt sluttstrek for arbeidet, men sunniene sto splittet i synet på det foreliggende utkastet. Spørsmålet om føderasjon og fordelingen av olje inntektene ble trukket mye lenger i retning av særlig det kurdiske utgangsstand punkt et enn mange sunnimuslimer egentlig var interessert $\mathrm{i}$ å gi etter for, mens for eksempel Iraqi Islamic Party støttet forslaget blant annet fordi de var positive til den prominente rollen shari'a ble gitt i lovverket. For mange ga nok likevel hele prosessen en besk bismak i munnen: 
Fra å ha vært utestengt fra prosessen, ble sunniene gisler for prosessens legitimitet uten at de fikk den innflytelsen de ønsket på det endelige resultatet. Det var derfor flere sunniledere som gikk imot forslaget, blant dem lederen for de sunnimuslimske forhandlerne i grunnlovskomiteen. ${ }^{\mathrm{I}}$

Nytt engasjement i den politiske prosessen I avstemningen over grunnloven I5. oktober 2005 stemte to governorater nei med minst to tredjedels flertall - ett nei mindre enn det som trengtes for å blokkere det foreliggende forslaget. For noen var dette det endelige beviset på at den politiske prosessen var illegitim og ikke verd å ta del $i$, for andre ga det støtet til ny deltakelse. Fra grunnlovsavstemningen til valget på ordinær nasjonalforsamling i desember 2005 var det bare to måneder, og Iraqi Islamic Party bestemte seg denne gangen for å delta.

Siden forrige valg hadde de ulike sunnipartiene dessuten omgruppert seg. Ghazi al-Yawers Iraqis - det eneste sunnipartiet som vant seter i januarvalget - slo seg sammen med sekulære (og sjiamuslimske) Iyad Allawi i den ikke-sekteriske listen Iraqi National List. ${ }^{\text {I4 }}$ Iraqi Islamic Party dannet på sin side Iraqi Accord Front ${ }^{15}$ sammen med andre sunnipartier. I tillegg fantes en tredje liste som samlet sunnimuslimer, kristne og kurdere under en paraply.

Som ved forrige valg var det de store sjiaog kurderlistene som var valgvinnerne: den sjiamuslimske listen United Iraqi Alliance $^{\mathrm{r} 6}$, som samlet de store, religiøse sjiapartiene, og den kurdiske listen Democratic Patriotic Alliance of Kurdistan ${ }^{17}$ som samlet majoriteten av de kurdiske partiene. Av listene som representerte sunnimus- limer var det de tre nevnt ovenfor som vant suverent flest stemmer, med henholdsvis 8 prosent, I5,I prosent og 4,I prosent. Det er verdt å merke seg at det var listen med den klareste sekteriske og religiøse profilen, Iraqi Accord Front, som fikk suverent størst oppslutning blant sunnimuslimene.

Det tok mange måneder med politisk tautrekking før den nye regjeringen kunne annonseres 20. mai 2006. De fleste og tyngste stillingene gikk til shia- og kurderpartiene, mens bare ni av 40 ministre var arabiske sunnimuslimer. ${ }^{18}$ Seks av sunniministrene kommer fra valglisten Iraqi Accord Front, to kommer fra Iraqi National List,

\section{Det er ubestridelig at sunnimuslimer har voert overrepresentert $i$ landets maktposisjoner.}

mens den siste er politisk uavhengig. Sunniene har riktignok fått noen få av de viktigste ministerpostene i den politiske toppledelsen i Irak: En av visepresidentene er Tariq al-Hashemi fra Iraqi Islamic Party. Deretter følger en av de to visestatsministerne i tillegg til forsvars- og justisministerne. De øvrige stillingene faller inn under litt mykere kategorier som kvinneanliggender, vitenskap og teknologi, høyere utdanning og planlegging - alle er utvilsomt viktige områder, men det er ikke her den virkelige maktkamp en i samfunnet utspiller seg.

\section{Politikk i Irak før Saddams fall}

Det at partiet med sterkest sekterisk profil fikk flest stemmer og stillinger i regjeringen, er viktig fordi det representerer noe 
nytt i Irak. For de arabiske sunnimuslimene i Saddam Husseins Irak, var verken det å være sunnimuslim eller det å være araber viktige størrelser når de skulle bevege seg i det politiske landskapet. Det som derimot var av betydning, var klan- og stammetilhørighet. Gjennom årene hadde Saddam Hussein utviklet et intrikat nettverk av støttespillere hvor han knyttet til seg familier og klaner som sine allierte ved å tildele dem makt, rikdom og posisjoner i bytte mot lojalitet. Siden Saddam Hussein var arabisk sunnimuslim, var det en naturlig følge av styrings systemet hans at store deler av maktapparatet og den politiske, militære og administra tive eliten var sunnimuslimer. Det er likevel viktig å legge merke til at de ikke fikk posisjonene sine fordi de var sunnimuslimer, men snarere fordi de var del av Saddams slektsbaserte makthierarki. Slektsbånd ble langt på vei sett på som en garanti for lojalitet.

For Iraks sjiamuslimer og kurdere var situasjonen motsatt. Det var riktignok mulig å få tilgang til Saddams nettverk også som sjia eller kurder, men nåløyet var mye trangere når man ikke hadde slektskapsbånd å vise til. Dermed ble både sjiamuslimer og kurdere underrepresentert i statsadministrasjon, politikk og forsvar, i tillegg til at de også var forfulgt politisk på grunnlag av sin religiøse eller etniske tilhørighet.

I begge tilfeller skyldtes dette at Saddam mistenkte at de næret sterkere lojalitet til andre størrelser enn Irak og hans regime. For kurdernes del var denne mistanken knyttet til den kurdiske drømmen om Kurdistan som selvstendig stat. For sjiaenes vedkommende hadde mistroen sammenheng med fiktive eller reelle bånd til Iran, og det faktum at sjiaene tidligere hadde mobilisert politisk som følge av at de var politisk underrepresentert. Dermed opplevde de en negativ spiral der underrepresentasjon førte til misnøye, som ble oppfattet som mistillit, og som ga støtet til ytterligere politisk undertrykkelse.

\section{Politisering av religion etter 2003}

På grunn av den nettverks- og slektskapsbaserte maktbasen til Saddam Hussein, var ikke religiøs tilhørighet noen viktig politisk størrelse. De fleste sunnimuslimene organiserte seg derfor heller i sekulært orienterte partier: For mange var Ba'th-partiet et naturlig valg - for andre et nødvendig valg for å få jobb. Mange knyttet seg også til Det irakiske kommunistpartiet, som periodevis hadde sterk oppslutning. Fra nittitallet fantes det i tillegg flere nasjonalistiske, sekulære partier - flere av disse hadde en forbindelse med hæren og sto i mange tilfeller for en irakisk linje i et politisk landskap hvor Ba'th-partiet i hvert fall på papiret heiste den pan-arabiske fanen.

Det at sunnimuslimene i hovedsak var organisert politisk etter andre kriterier enn religiøs tilhørighet ble et problem i Irak etter Saddam Hussein. Etter den amerikanske invasjonen mistet klantilhørighet mye av sin betydning, mens religion ble den fremste meningsbærende politiske kategorien. Noe av forklaringen til dette er antagelig å finne $i$ den amerikanske okkupasjonsmakten. Da usA styrtet Saddam Hussein fikk de stor innflytelse på hvem som skulle overta etter ham. Paul Bremer, nyslått leder av Coalition Provisional Authority, tildelte plasser i Iraqi Governing Council på grunnlag av etnisk

En pilgrim på vei til Kerbala bærer på et sjiaflagg. 


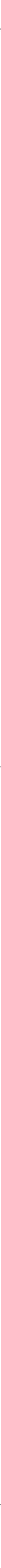


eller religiøs bakgrunn. ${ }^{19}$ Denne avgjørelsen var antagelig preget av at USA $i$ mange år hadde støttet irakiske eksilpolitikere som fikk solgt inn sin virkelighetsforståelse hos amerikanske beslutningstagere. I eksilmiljøet var det mange sjiamuslimer og kurdere, og deres beretninger om politisk forfølgelse på grunnlag av religion og etnisitet ble dermed sentral i den amerikanske forståelsen av politikk i Irak.

En annen årsak til at irakiske sunnier i økende grad begynte å se på seg selv som en gruppe, kan være å finne i to avgjørelser tatt i mai 2003 av Bremer. Umiddelbart etter hans ankomst i Irak, annonserte han at hele statsapparatet skulle de-ba'thifiseres. Dette betydde i klartekst at alle høytstående medlemmer av det tidligere regjeringspartiet umiddelbart ville miste sine poster, og at de heller ikke ville kunne få nye offentlige stillinger. Også ordinære medlemmer ble rammet av prosessen, men for disse var det i mange tilfeller mulig å anke avgjørelsen. Ankemuligheter eller ikke - resultatet var uansett at store deler av embetsverket ble avsatt med øyeblikkelig virkning, og titusener ble arbeidsløse. ${ }^{\circ \circ}$ En uke senere fulgte Bremer opp med å oppløse hele den irakiske hæren. Dermed ble flerfoldige hundretusen irakiske menn arbeidsledige, hvorav en god andel var sunnimuslimer. ${ }^{2 \mathrm{I}}$

Eksklusjonen fra arbeidsmarkedet var i praksis sammenfallende med religiøs tilhørighet. I ukene etter at krigen startet i mars 2003, startet dessuten en voldsbølge hvor tidligere Ba'th-partimedlem mer ble regelrett henrettet, ofte sammen med familiene sine, i det som bar preg av rene hevnaksjoner. $^{22}$ Dette fungerte som en katalysator for den identitetsskapende prosessen. Senere fulgte nattlige raid med likvidasjoner av sunnimuslimer, utført av sjiamilitser som en reaksjon på terrorgruppers selvmords aksjoner mot sivile sjiamuslimer. Disse faktorene er elementer som bidrar til å forklare fremveksten av en ny identitet for sunnimuslimer, basert nettopp på deres sekteriske tilhørighet.

Det er også et poeng at alt dette fant sted på et tidspunkt hvor den irakiske staten hadde brutt fullstendig sammen. Samtidig skulle ressurser fordeles i befolkningen, og de tidligere fordelingsprinsippene sto nå for fall. Kampen om å definere de nye kriteriene for hvordan penger og makt skulle distribueres var hard, og de religiøse og etniske institusjonene hadde overlevd

\section{På valgdagen møtte få sunni- muslimer opp for å stemme, i sterk kontrast til sjiaer og kurdere.}

regimeskiftet, i motsetning til den irakiske staten slik vi kjente den fram til da. Det var derfor disse institusjonene som overtok styringen i fraværet av en statsmakt, og dette bidro til å forme den politiske virkeligheten.

\section{Et hestehodes forsprang}

Sjiaene og kurderne fikk dermed et hestehodes forsprang. På grunn av den etnisk og religiøst betingede undertrykkelsen av disse gruppene, hadde de allerede sterke partiorganisasjoner med lange historiske røtter og til dels godt utviklet statsapparat. For sjiamuslimene var de viktigste partiene Da'wa-partiet og Supreme Council for Islamic Revolution in Iraq (SCIRI). Da'wa 
ble stiftet i I957-58, mens SCIRI ikke dukket opp på den irakiske scenen før tidlig på 8o-tallet. Begge partiene arbeidet for en islamisering av samfunnet og var sterkt kritiske til de sekulære regimene som styrte Irak. ${ }^{23}$

I Nord-Irak var de viktigste partiene KDP (Democratic Party of Kurdistan) og PUK (Patriotic Union of Kurdistan). Begge var i utgangspunktet basert på kommunistisk tankegods, men politikken var i praksis preget mer av lederne enn av ideologi, og for lederne var kurdernes rettigheter og framtid et svært viktig aspekt av det politiske arbeidet. ${ }^{24}$ Disse partiene kom til å dominere den irakiske samfunnsdebatten og politiske prosessen etter 2003 og vant også knusende seiere i valgene i 2005 .

Det fantes imidlertid også et politisk parti som var fundert på sunni-islam, nemlig Iraqi Islamic Party (Iı)). Partiet ble stiftet på I96o-tallet av Det muslimske brorskapet som opprinnelig ønsket å samle både sunni- og sjiamuslimer i ett parti som skulle arbeide mot sekularismen. Dette motsatte imidlertid høytstående representanter for sjiapresteskapet seg, og resultatet var at iı ble et rent sunni-parti. I sitt politiske manifest fastslo de at de ville arbeide for en islamsk stat i Irak basert på shari'a..$^{25}$ Bakgrunnen for opprettelsen av partiet var altså ikke at de ønsket å mobilisere på grunnlag av at de var sunnimuslimer i motsetning til sjiamuslimer, men snarere at de sto i opposisjon til det sekulært orienterte sunniregimet som satt ved makten.

\section{Sunnimuslimene samler seg}

Som en følge av det sterke fokuset på religion som et ordnende prinsipp i politikken, ble det tvunget fram en institusjonalisering av sunni-islam i Irak som man ikke hadde sett før. De sekulære partiene beholdt en del av sin appell, men deres budskap var i stor grad bygget opp rundt deltakelse i den politiske prosessen under amerikansk okkupasjon. I denne konteksten framsto plutselig IIP, men også organisasjoner som Muslim Scholars Association som partier med sterkere appell til flere enn tidligere. Disse tok tydelig avstand fra drapene på irakere som de voldelige motstandsgruppene sto for, men var samtidig sterke kritikere og motstandere av okkupasjonen, og kanskje ennå viktigere: tydelige forsvarere av sunnimuslimenes interesser.

Muslim Scholars Association ble dannet bare dager etter at den amerikanske invasjonen begynte i 2003, og samlet store deler av imamene og de lærde blant landets sunnimuslimer. I tiden rundt de amerikanske styrkenes offensiv mot Falluja, i april 2004, fikk organisasjonen stor oppslutning fordi de, i likhet med mange irakere, tok sterk avstand fra stormangrepet og beleiringen av byen, mens den sittende regjeringen ble tvunget til å støtte den under sterkt amerikansk press. Selv om organisasjonen ikke støtter vold mot sivile, har de hatt en retorikk som ligger nært opp til den som føres av jihadistiske terrorgrupper. Ambisjonen deres var å samle alle Iraks sunnimuslimer ved å fungere nærmest som motparten til sjiaenes storayatollah Ali al-Sistani, som er det høyeste religiøse overhodet for Iraks sjiamuslimer. ${ }^{26}$

Muslim Scholars Association ble imidlertid på utfordret denne målsetningen fra flere hold. Ahmad 'Abd al-Ghafour alSamarra'i, daværende minister for sunnimuslimske religiøse stiftelser, står for en mer moderat linje. ${ }^{27}$ Han har foreslått å opprette et majlis al-ifta' eller fatwa-råd hvor 
så mange som 250 imamer samles og hvis uttalelser skal fungere autoritativt for Iraks sunnimuslimer. ${ }^{28}$ Verken ministeriet eller Muslim Scholars Association har imidlertid greid å etablere seg som den udiskutable autoriteten for sunniene så langt. Sistnevnte har spilt seg selv ut over sidelinjen ved å nekte enhver befatning med den politiske prosessen så lenge landet er under amerikansk okkupasjon. I prosessen har de støtt fra seg både de moderate kreftene blant sunniene, og i tillegg de sterkeste aktørene blant sjiaene og kurderne. Problemet for ministeriet ligger antagelig i deres sterke bånd til regjering og statsapparat. Som både al-Samarra'i og hans forgjenger har fått erfare, kan en politisk utnevnt leder med letthet byttes ut hvis han ikke taler i tråd med regjeringens synspunkter. Dermed mister ministeren mye av sin politiske tyngde og autoritet.

Utviklingen av nye religiøse institusjoner og den økende styrken til religiøst funderte partier innen sunni-islam ser ut til å være et sentralt trekk ved den politiske utviklingen i Irak etter 2003. Iraqi Islamic Party har med sin regjeringsdel tak else befestet sin posisjon som en politisk bevegelse med påvirkningskraft, og dette er mulig fordi religion har blitt det viktigste ordnende prinsippet i irakisk politikk. Sunnimuslimene har unngått å bli en politisk paria ved å tilpasse seg den nye virkeligheten: De har vraket de gamle, sekulære tradisjonene, og satser i stedet på nye, religiøse partier.

\section{$\cdot f \cdot$}

I Jeg vil for enkelthets skyld referere til gruppen som (Iraks) sunnimuslimer, selv om også en majoritet av de irakiske kurderne er sunnimuslimer. Når det er snakk om sistnevnte vil jeg referere til disse som kurdere.

2 Det er ikke gjort noen folketelling i Irak som har gjort 28 rede for religiøs og etnisk tilhørighet - dette har vært et ømtålig emne. Anslagene varierer dermed en del. To ulike amerikanske kilder oppgir henholdsvis 20 og 15 prosent: Council on Foreign Relations (I4.I0.2005): "Iraq's Sunni Arabs". www.cfr.org/publication/9027/, og Global Security: "Sunni Islam in Iraq". www.globalsecurity.org/military/ world/Iraq/religion-sunni.htm

3 Hay'at al-'ulama' al-muslimin. Det er vanskelig å orientere seg i jungelen av irakiske partier. Jeg vil bruke de engelske oversettelsene for å unngå ytterligere forvirring ved å oversette til norsk. For noen partier finnes det flere engelske betegnelser. I disse tilfellene vil jeg bruke den varianten jeg oppfatter som mest brukt. Alle partinavn vil oppgis på arabisk i fotnote første gang de nevnes.

4 Hizb al-islami al-'iraqi.

5 Tajammu' al-dimuqratiyyin al-mustaqallin.

6 Radio Free Europe (2005): "Getting out the Sunni Vote". www.rferl.org/specials/iraqelections/articles/sunnivote .asp.

7 Independent Electoral Commission of Iraq (II.02.2005). www.ieciraq.org

8 Guardian (I4.02.2005), "Iraq's Shias in landmark poll victory”. http://www.guardian.co.uk/international/story/ o,,I4I2277,00.html

9 Independent Electoral Commission of Iraq (II.02.2005). www.ieciraq.org

Io Al-'iraqiyyun. Ikke å forveksle med Iraqi List (al-qa'ima al'iraqiyya).

II Radio Free Europe/Radio Liberty (20.06.2005): "Iraq Report", vol. 8, nr. 20.

I2 Radio Free Europe/Radio Liberty (31.08.2005): "Sunnis weigh in on draft constitution'.

I3 ввС (30.08.2005): 'Sunni call to reject Iraq charter'. http://news.bbc.co.uk/2/hi/middle_east/4I98370.stm.

I4 Al-qa'ima al-'iraqiyya al-wataniyya.

I5 Jabhat al-tawafuq al-'iraqiyya.

I6 Al-i'tilaf al-'iraqi al-muwahhad.

I7 Q'imat al-tahaluf al-kurdistani.

I8 Dette er et område hvor det er vanskelig å finne pålitelige kilder. Opptellingen til denne artikkelen er i hovedsak basert på en oversikt laget av Education for Peace in Iraq Center (www.epic-usa.org/files/EPIC/IRAQ_Government. pdf), som arbeider med å sette det politiske miljøet $\mathrm{i}$ Washington i kontakt med irakere i Irak som kan bidra til å øke amerikanske beslutningstageres kunnskaper. Det er imidlertid vanskelig å finne ut av hva slags organisasjon dette er, og hvem som finansierer dem. Se www.wpicusa.org for mer informasjon.

I9 Meijer, Roel: “The Association of Muslim Scholars in Iraq' i The Middle East Report, nr. 237, vinteren 2005. http://www.merip.org/mer/mer237/meijer.html.

20 The New Yorker (I5.II.2004) “Letter from Iraq: Out on the 
streets". http://www.newyorker.com/printables/fact/ 04III5fa_fact

2I Guardian (26.08.2003) "Get Real". http://www.guardian. co.uk/elsewhere/journalist/story/o,,I029595,00.html

22 The New Yorker (I5.II.2004) "Letter from Iraq: Out on the streets".

23 Tripp, Charles (2000): «A history of Iraq». Cambridge: Cambridge University Press.

24 Ibid.

25 Al-'Azami, Basim: "The Muslim Brotherhood: Genesis and Development" i Faleh Abdul-Jabar (red.) «Ayatollahs, Sufis and Ideologues. State Religion and Social Movements in Iraq». London: Saqi Books, 2002: 162-I76.

26 Meijer (2005).

27 Al-Samarra'i ble avsatt av statsminister al-Maliki 2I.02.2007 i kjølvannet av en voldtektssak i Bagdad hvor en sunnimuslimsk kvinne anmeldte sjiamuslimske politimenn for å ha voldtatt henne under en razzia. AlSamarra'i bestrider al-Malikis rett til å avsette ham, og saken er ikke avgjort i skrivende stund.

28 Intervju med Ahmad al-Samarra'i i Oslo, 6. desember 2006. 